\title{
BIOEDUSCIENCE
}

\section{Phenetic Kinship Relationship of Apocynaceae Family Based on Morphological and Anatomical Characters}

\author{
Ahsanul Buduri Agustiar1, Dewi Masyitoh ${ }^{1}$, Irda Dwi Fibriana ${ }^{1}$, Adesilvi Saisatul Khumairoh1, Kurnia Alfi Rianti ${ }^{1}$, Norma \\ Fitriani $^{1}$, Muhammad Harissuddin ${ }^{1}$, Hafidha Asni Akmalia ${ }^{1}$ \\ ${ }^{1}$ Pendidikan Biologi, Universitas Islam Negeri Walisongo, Jl. Walisongo No.3-5, Semarang, Jawa Tengah, Indonesia 50185 \\ *Corespondent Email: ahsanulagustiar@gmail.com
}

\section{ARTICLE INFO}

Article history

Received: 20 Apr 2020

Accepted: 01 Des 2020

Published: 31 Des 2020

\section{Keywords:}

Adenium obesum

Allamanda cathartica

Catharanthus roseus

Phenetic

Plumeria rubra

\begin{abstract}
A B S T R A C T
Background: Biodiversity in Indonesia is so diverse, including in Apocynaceae plants, that is why it is essential to study the kinship relationship to find out the kinship of Apocynaceae. The purpose of this study was to determine phenetic kinship through morphological and anatomical evidence from four members of the Apocynaceae family. Methods: The method used in this research is a descriptive qualitative and quantitative method. The indicators used are morphological features of the stems, leaves, and flowers and the stomata's anatomical features. The samples in this study were four Apocynaceae family members species, including Adenium obesum, Plumeria rubra, Catharanthus roseus, and Allamanda cathartica. Results: The result showed that the phenetic kinship Alamanda cathartica had the most distant kinship relationship with a similarity value of $31 \%$ compared to the other three species in the family Apocynaceae. Phenetic; morphology; anatomy; Adenium obesum; Catharanthus roseus; Allamanda cathartica; Plumeria rubra. Conclusions: Thus, the familial relationship between species in the Apocynaceae family in terms of morphological and anatomical characters, the closest kinship is Plumeria rubra, and Adenium obesum with a similarity value of $44 \%$ and the most distant Alamanda cathartica with a similarity value of $31 \%$.
\end{abstract}

Hubungan Kekerabatan Fenetik Famili Apocynaceae Berdasarkan Karakter Morfologi dan Anatomi

\begin{abstract}
A B S T R A K
Background: Keanekaragaman hayati di Indonesia begitu beragam termasuk juga pada tumbuhan famili Apocynaceae oleh sebab itu kajian hubungan kekerabatan penting dilakukan untuk mengetahui kekerabatan tumbuhan famili Apocynaceae. Tujuan dari penelitian ini untuk mengetahui/menganalisis kekerabatan fenetik melalui bukti morfologi dan anatomi dari empat anggota famili Apocynaceae. Metode: Metode yang digunakan dalam penelitian ini merupakan metode kualitatif dan kuantitatif deskriptif. Indikator yang digunakan adalah ciri morfologi batang, daun, dan bunga serta ciri anatomi yaitu tipe stomata. Sampel dalam penelitian ini yaitu empat spesies anggota famili Apocynaceae, antara lain Adenium obesum, Plumeria rubra, Catharanthus roseus, dan Allamanda cathartica. Hasil: Penelitian menunjukkan bahwa hubungan kekerabatan fenetik Alamanda cathartica mempunyai hubungan kekerabatan yang paling jauh dengan nilai similaritas 31\% dibanding ketiga spesies lain anggota famili Apocynaceae. Fenetik; morfologi; anatomi; Adenium obesum; Catharanthus roseus; Allamanda cathartica; Plumeria rubra. Kesimpulan: Dengan demikian hubungan kekerabatan antara spesies pada family Apocynaceae ditinjau dari karakter morfologi dan anatomi mempunyai hubungan kekerabatan yang dekat yaitu spesies Plumeria rubra dan Adenium obesum dengan nilai similaritas $44 \%$ dan yang paling jauh yaitu Alamanda cathartica dengan nilai similaritas yakni 31\%.
\end{abstract}

(C) 2020 by authors. Lisensi Bioeduscience, UHAMKA, Jakarta. This article is open access distributed under the Creative Commons Attribution terms and conditions (CC-BY) license.

\section{Introduction}

Biodiversity in Indonesia is very diverse, especially in the Plant or Plant Kingdom, where the Plant Kingdom is known as a group of organisms with chlorophyll and different other uniqueness. The large number of members of the Plantae kingdom resulted in the subdividing of the Plantae kingdom into several divisions, such as Spermatophyta. They are then grouped into more specific 
groups, namely subdivisions, such as angiosperms. Angiosperms are a group of seed plants that produce reproductive structures, namely fruit and flowers. Angiosperms are derived from the Greek word Angion, which means that the container refers to the fruit which is the container for the seed or the ripe ovary. Angiosperms are a very diverse and widespread group of plants compared to other plant groups. There are more than 250,000 species of angiosperms living on earth (about $90 \%$ of all plant species) (Campbell, 2012).

Kinship is very important because it can make it easier to classify several species of taxonomy. Thus, this study uses phenetic kinship to determine the similarity of several species of the Apocynaceae family through the morphological and anatomical dendrogram of several species of stomata belonging to the Apocynaceae. The phenetic method is a method with a numerical analysis approach for numerical compilation. The scope of the phenetic approach includes the calculation of the index of inequalities, the analysis of patterns, the index of diversity and various other indices. All subjects and factors analyzed in the phenetic approach have the same status (Noor, 2014).

One of the aspects used in the phenetic method is the morphological approach which focuses on the stature and structure of the plant body. Morphology aims to identify visually so that the enormous diversity of plants can be identified and classified and given the correct name for each group formed. The scope of plant morphology not only determines the shape and composition of the plant body, but morphology also identifies the function determinations of each part of plant life, and then tries to find out where the origin and structure of the body is formed (Wahyu, 2016). In addition to studying plant morphology, anatomy studies are also essential to know them within plants.

According to (H, George. F. George J, 2006), plant anatomy examines the structure and forms of parts in plant organs, one of which is the structural function. The anatomical evidence that can be used in the relationship of parenthood is stomata. Stomata are small leaf openings, which when opened to the maximum, are only $0.0001 \mathrm{~mm}$. Most of the leaves have stomata which are concentrated on the underside of the leaves and have a frequency of 100 $100,000 \mathrm{~cm}^{2}$. The stomata is flanked by guard cells. Unlike other cells in the lower leaf epidermis, the guard cells contain chloroplasts.

Apocynaceae is a family of the Spermatophyta division which has features such as twisted crowns, elongated oval leaves, shiny leaves, stone fruit and spherical fruit, hairy flower protrusions, and tightly clustered leaves on the tip of the branch (Ping-Tao, 1995). In the research of (Rahmawati et al., 2016), the research method used in their research is descriptive. Parameters are used, namely the morphological characteristics of stems, leaves, flowers, fruit and seeds and the type of habitus. In that study only used morphological observations. Nevertheless, in our study, we used additional parameters in the form of anatomical observations, namely the stomata.

This study aims to determine the kinship of the Apocynaceae by using morphological and anatomical characteristics. The purpose of this study was to determine phenetic kinship through morphological and anatomical evidence from four members of the Apocynaceae.

\section{Methods}

The research was carried out around Campus II of Walisongo State Islamic University Semarang in May 2019. The stages of the process carried out in this study are depicted in Figure 1.

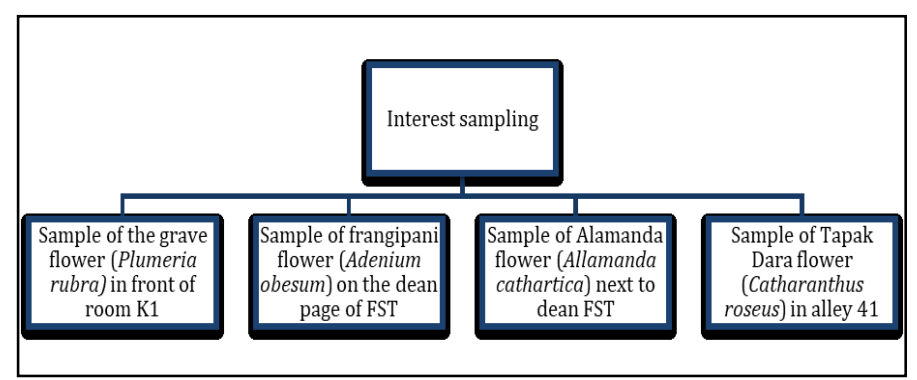

Figure 1. Flower sampling process chart

Tools used to carry out the research include a stereo microscope, camera, ruler, razor blade, preparations and cover glasses, beakers and dropper glasses, distilled water. Descriptive quantitative and qualitative methods have been used in this study to interpret and describe the morphology of several members of the Apocynaceae family.

Morphological characters are identified using clues based on the similarity of characters that are identified using clues based on the similarity of characters of plant species. Meanwhile, qualitative methods were used to analyze the anatomical characters of plants. The qualitative methods were used descriptive which must describe and reveal facts in the field by collecting data on leaf stomata of Apocynaceae members.

Morphological identification was carried out by adopting the modified (Rahayu, 2008) method, namely form, size and number characters such as flowers, stems, and also leaves. The method of making preparations for observing stomata using the replica method adopted by (Haryanti, 2010), namely by cutting the leaves as thin as possible and then observing them so that the stomata from the flower samples can be seen.

\section{Results}

The results of the parameters of 4 species of the Apocynaceae family based on morphological characters are shown in Table 1. All species of members of the Apocynaceae are more common in terms of roots, stems, leaves and flowers, i.e. Plumeria rubra, Catharanthus roseus, and Adenium obesum. Meanwhile, Alamanda cathartica has 
the characters of roots, stems, leaves, and flowers that are the most different from the other three species of members of the Apocynaceae. The difference in morphology of each of the most pond species is the length of the flower, Plumeria rubra has a flower length of $5.87 \mathrm{~cm}$, Catharanthus roseus has a flower length of $2.8 \mathrm{~cm}$, Alamanda cathartica has a flower length of $8.13 \mathrm{~cm}$ and Adenium obesum has a flower length $7.32 \mathrm{~cm}$.

Based on the image shown, it can be seen that the colors of the flower crowns of the Apocynaceae in 4 species have different colors, namely the color of the Plumeria rubra flower crown, the color of the Alamanda cathartica flower, the color of the crown of the Cantharanthus roseus flower, and the color of the crown of the Adenium obesum flower.

The results of the morphological observations of each of the four species of the Apocynaceae can be seen as follows, Plumeria rubra, has an elongated leaf shape with dark green color, tapered leaf tips, tapered leaf base, pinnate leaf pinnacles, leaf surface gloomy, flat-leaf edge, longleaf $34 \mathrm{~cm}$ and leaf width $12 \mathrm{~cm}$. The number of crowns is 5, the type of flower is classified as compound interest, the location of the lateral flower, with the flower color, is a mixture of mixed yellowish white. The stems grow perpendicular to the shape of a round stem, branching of the stems (dichotomous), the types of woody stems, and the surface of the stems showing leaf marks.

Alamanda cathartica L. has a long, light green leaf shape, tapered tip, blunt leaf base, pinnate leaf blade, smooth webbed leaf surface, flat-leaf edge $9 \mathrm{~cm}$ long and $3.7 \mathrm{~cm}$ wide. The number of flower crowns is 5, the type of compound interest, the location of the lateral flowers, is yellow. The direction of growth of the stem is perpendicular, the shape of the stem is round, the branching of the stem is stretched (dichotomous), the type of woody stem with the surface shows a lot of lenticels.

Table 1. Results of the Apocynaceae family parameters for the species Plumeria rubra, Catharanthus roseus, Allamanda chatartica and Adenium obesum

\begin{tabular}{|c|c|c|c|c|}
\hline \multirow[b]{2}{*}{ Evidence } & \multicolumn{4}{|c|}{ Species family Apocynaceae } \\
\hline & Plumeria rubra & Catharanthus roseus & $\begin{array}{l}\text { Allamanda } \\
\text { chatartica }\end{array}$ & Adenium obesum \\
\hline Habitus & Shrub & Bush & Shrub climbs & Bush \\
\hline Leaf shape & Ellipse & Ellipse & Ellipsed & Ellipse \\
\hline Leaf tip & Tapered & Round like an egg & Tapered & Rounded \\
\hline Leaf base & Blunt & Blunt & Blunt & Pointed \\
\hline Leaf flesh & Like paper & Like paper & Like membrane & Like paper \\
\hline Leaf top surface color & Dark green & Dark green & Light green & Dark green \\
\hline Underside color of leaves & Green & Green & Dark green & Green \\
\hline Top surface ornamentation of leaves & Gloomy slippery & Downy & Smooth webbed & Slippery \\
\hline Lower surface ornamentation of leaves & Gloomy slippery & Downy & Smooth webbed & Slippery \\
\hline Petiole & Long & Long & Short & Short \\
\hline Leaf length & $35,5 \mathrm{~cm}$ & $3 \mathrm{~cm}$ & $12,63 \mathrm{~cm}$ & $21,82 \mathrm{~cm}$ \\
\hline Leaf width & $10,3 \mathrm{~cm}$ & $1,5 \mathrm{~cm}$ & $3,7 \mathrm{~cm}$ & $6 \mathrm{~cm}$ \\
\hline Leaf bud & Wild & Wild & Wild & Wild \\
\hline Stem surface & Showing leaf marks & Showing leaf marks & Lots of lenticels & Showing leaf marks \\
\hline Stem color & brown & brown & Brownish green & Grey \\
\hline Stem height & $2-7 \mathrm{~m}$ & $0,2-0,8 \mathrm{~m}$ & $3-8 \mathrm{~m}$ & $50-100 \mathrm{~cm}$ \\
\hline Root shape & Spear roots & Spear roots & Spear roots & Root twist \\
\hline Root types & Tap roots & Fibrous roots & Tap roots & Supporting roots \\
\hline Root color & Grey & Brown & Brown & Grey \\
\hline Location of flowers & flos terminalis & flos lateralis & flos lateralis & flos terminalis \\
\hline Stamens & Not have & Have & Not have & Not have \\
\hline Color of flower crown & Yellowish pink & Lavender & Yellow & Pink \\
\hline Flower shape & Butterfly & Trumpet & Trumpet & Trumpet \\
\hline Flower gender & flos femineus & flos hemaproditus & flos femineus & flos femineus \\
\hline Flower base & valvata & torsiva & Torsiva & torsiva \\
\hline Fragrant flowers & Fragrant & Fragrant & Not fragrant & Fragrant \\
\hline Flower house & Housed two & Single house & Housed two & Housed two \\
\hline Flower petal shape & Taper & Round & Round & Round \\
\hline Floer surface & Slippery & Coarse & Slippery & Coarse \\
\hline Types of stamens & Not have & Not have & Not have & Not have \\
\hline Boundary compound interest & Fan flower & $\begin{array}{l}\text { Trumpet flower } \\
\text { (cicinus) }\end{array}$ & $\begin{array}{l}\text { Trumpet flower } \\
\text { (cicinus) }\end{array}$ & $\begin{array}{l}\text { Trumpet flower } \\
\text { (cicinus) }\end{array}$ \\
\hline Flower length & $5,87 \mathrm{~cm}$ & $2,8 \mathrm{~cm}$ & $8,13 \mathrm{~cm}$ & $7,32 \mathrm{~cm}$ \\
\hline
\end{tabular}



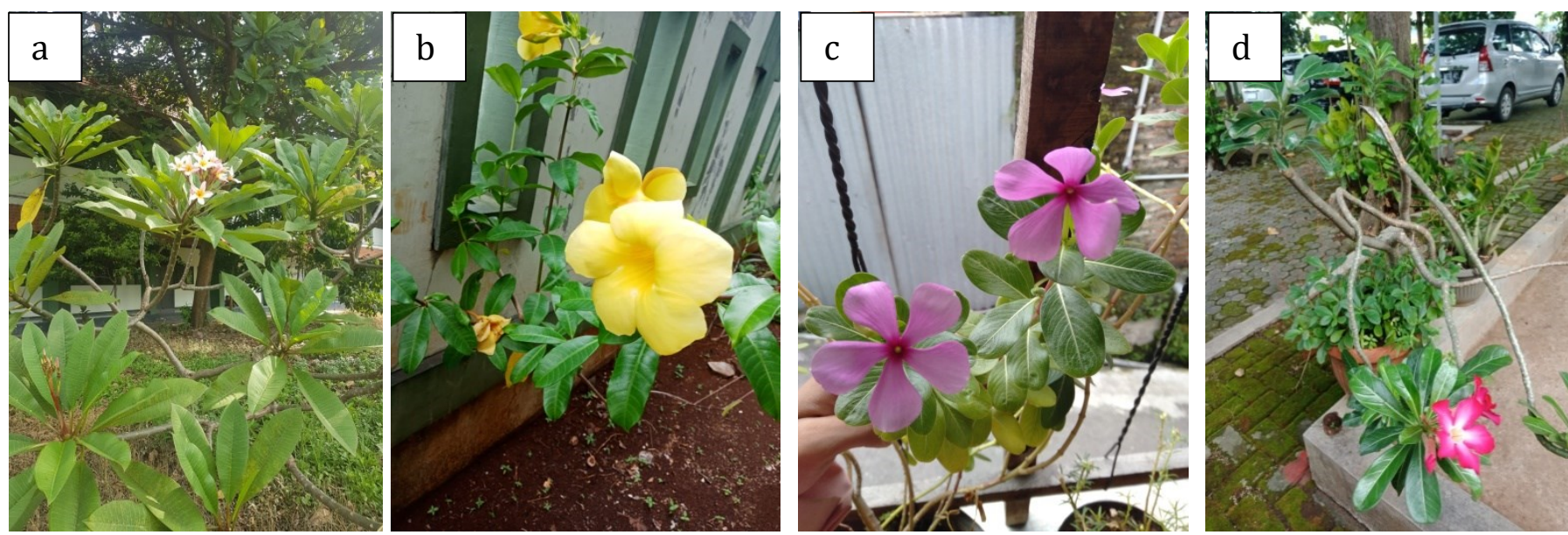

Figure 2. a). Color of flower crown Plumeria rubra, b). Color of flower crown Alamanda cathartica, c). Color of flower crown Cantharanthus roseus, d). Color of flower crown Adenium obesum.

Cantharanthus roseus has a jorong leaf shape with dark green color, blunt leaf tip, blunt leaf base, pinnate and pinnate, smooth and tight leaf surface, flat-leaf edge $4.4 \mathrm{~cm}$ long and $2.4 \mathrm{~cm}$ wide. The number of flower crowns is 5 , the type of compound flower, the location of the lateral flowers, and the lavender color. The direction of growth of the stems is perpendicular, the shape of the stems is round, the branching of the stems is dichotomous, the type of woody stems, the surface of the stems shows many leaf marks.

Adenium obesum, has an ellipse leaf shape with dark green color, blunt leaf tip, tapered leaf base, pinnate leaf blade, smooth glossy leaf surface, flat-leaf edge, $7.2 \mathrm{~cm}$ longleaf, and $3 \mathrm{~cm}$ wide leaf. The number of flower crowns is 5 , the type of compound flower, the location of the lateral flowers, and the color of the white and red Fanta flowers. The direction of growth of the stem is perpendicular, round in shape, branching of the stems (dichotomous), types of woody stems, the surface of the stems shows many leaf traces.

\section{Anatomical Analysis Results}

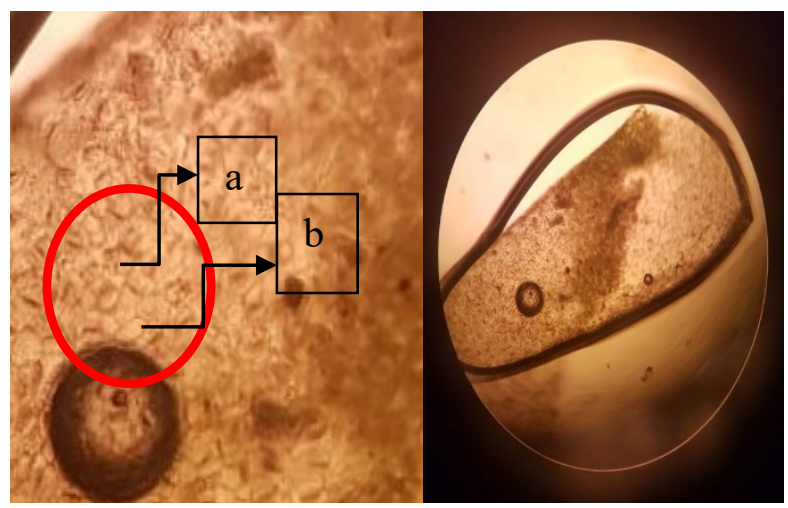

Figure 3. Paracytic/Rubiacous stomata type from Alamanda cathartica (magnification 12,5×10), a). Guard cells and; b). Neighboring cells.

The results of the observation of anatomical analysis using a stereomicroscope showed that the stomata of the

Apocynaceae family in the Alamanda cathartica species had different types of stomata from the other three species.

Results of Apocynaceae Family Parameters on Plumeria rubra, Catharanthus roseus, Allamanda chatartica, and Adenium obesum species presented in a dendrogram.

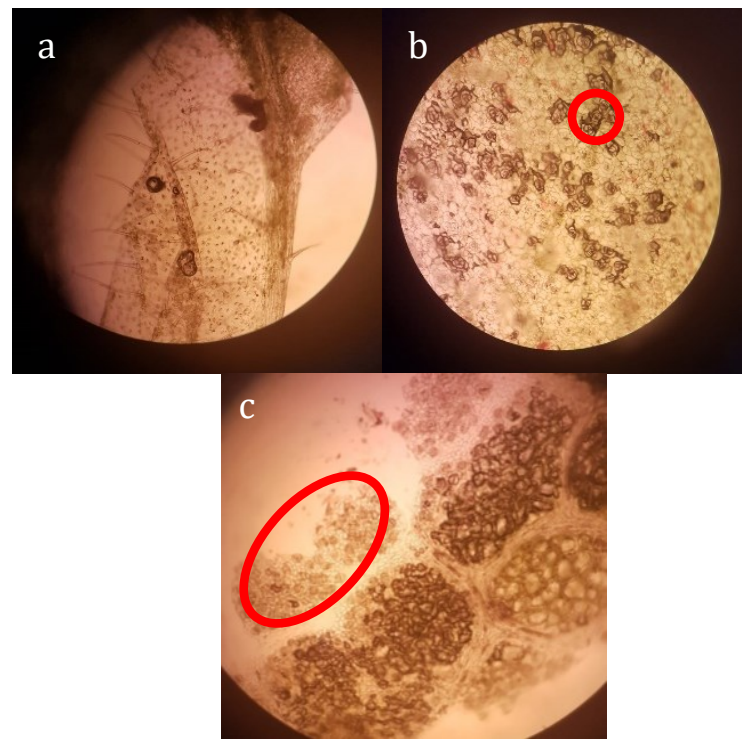

Figure 4. a) Catharanthus roseus, b). Adenium obesum, and c). Plumeria rubra has an Anomocytic/Ranunculaceous stomata type (magnification $4 \times 10$ ).

\section{Discussions}

The results of the relationship analysis of four species of the Apocynaceae based on morphological characteristics of stems, leaves, and owers showed different characters in each species found around campus II of UIN Walisongo Semarang. Plumeria rubra, Catharanthus roseus and Adenium obesum are closely related because there are many similarities in terms of roots, stems, leaves, and owers. Meanwhile, Alamanda cathartica has the characters of roots, stems, leaves, and owers that are the most different from the 


\section{Dendogram Apocynaceae}

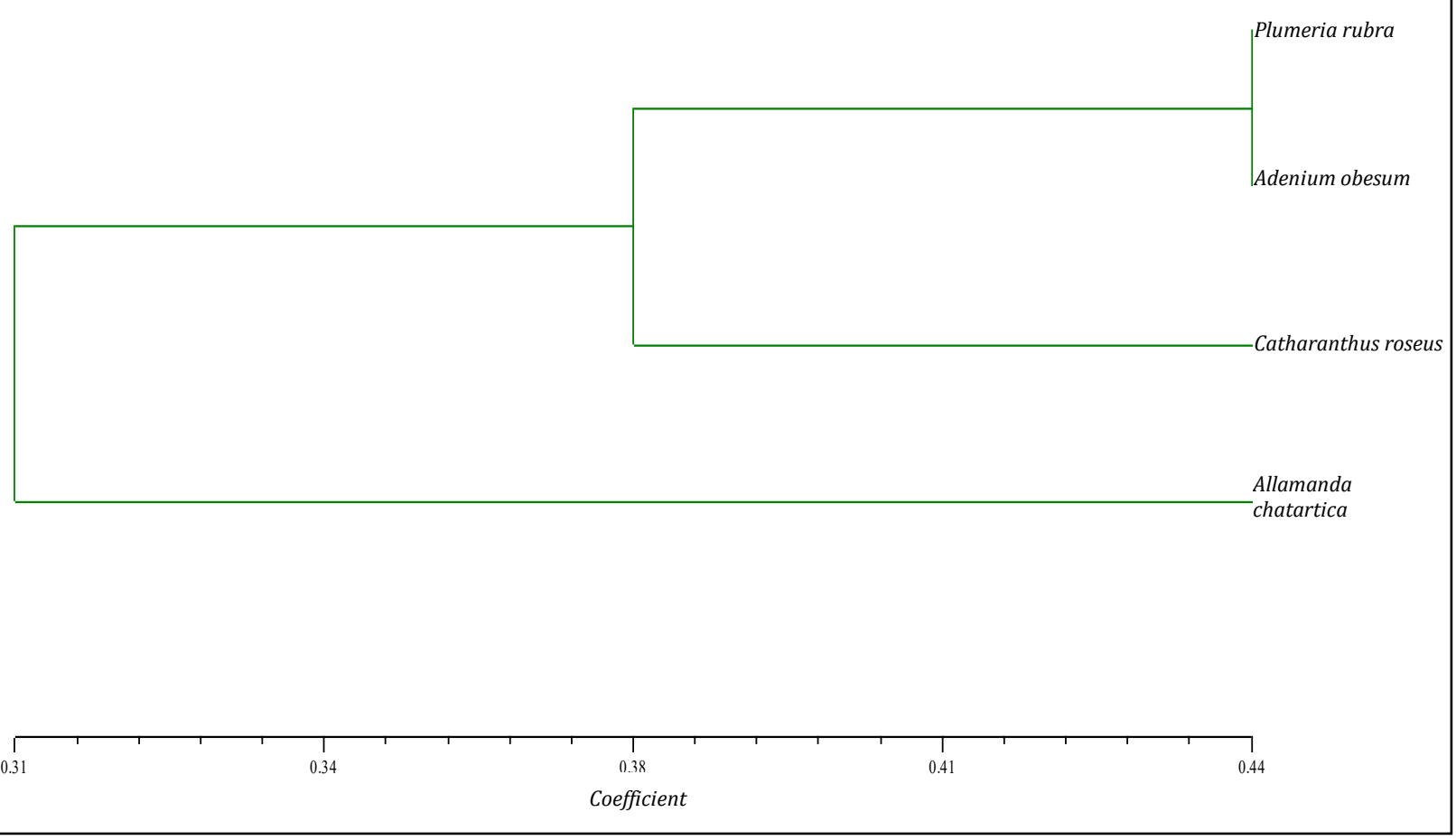

Figure 5. Dendogram of the Apocynaceae family in Plumeria rubra, Catharanthus roseus, Allamanda chatartica, and Adenium obesum species.

other three species of members of the Apocynaceae. So it can be seen that morphologically, trees, shrubs, or shrubs often climb and gummy-single leaf opposite or in a bouquet, without leaves and at edges. Flowers in umbrella children or at panicle or panicle trumpets rarely stand alone, irregular, and sex 2, most have 5 (Steenis, 2008).

The morphological characters analyzed showed a kinship between 4 species. In the dendrogram (Figure 4), it can be seen that the species group that was separated rst and formed an outgroup was Alamanda cathartica with a similarity coefcient value of $31 \%$. The grouping of the Alamanda cathartica, which separates from the other three groups because it has several different characteristics from other species. Different characters include root color, leaf surface, stem surface, ower color, leaf shape, crown color, leaf top surface ornamentation, and leaf flesh.

Meanwhile, the similarity coefficient value of $38 \%$ was formed by the Catharanthus roseus group. This species forms an outgroup of the other two groups. The grouping of Catharanthus roseus separated from 2 groups because it has several characters, including stem color, leaf surface, leaf shape. Meanwhile, Plumeria rubra and Adenium obesum formed one group with a similarity coefcient of $44 \%$. Thus, it can be seen that Plumeria rubra and Adenium obesum are closely related, namely based on stem color, leaf esh, leaf shape, leaf top and bottom surface color, and leaf buds. This concurs with Rahmawati et al. (2016) that the phenetic kinship relationship of seven members of the Apocynaceae family, there are three kinship categories, namely very close, close, and not close. An intimate relationship was shown in the combination of Allamanda cathartica and Nerium oleander species with an IS value of 0.38. In the research Sennblad and Bremer (1996) that Thevetia, Allamanda, and Plumeria have a close kinship. This is in line with research El Gazzar et al., (2018) that Plumeria and Catharanthus have a close phonetic relationship. Stomata with epidermis and neighbouring cells are classified separately with classification based on development. However, different types can occur in the same family or leaves of the same species (Haryanti, 2010).

The anatomy of the stomata of the Apocynaceae group members based on the results of the observations made shows that:

a. Alamanda cathartica, has a Paracytic/Rubiacous stomata type. Paracytic/Rubiacous stomata types are stomata that are surrounded by two additional cells (guard cells and neighbouring cells) which are parallel to the axis of neighbouring cells and apertures (Anitha, 2019). Parasitic type stomata are found in the paradermal section of the lower surface of the Alamanda cathartica leaf in Figure $3 \mathrm{a}$ and Figure $3 \mathrm{~b}$, which are observed with a stereomicroscope. Figure 3a shows the presence of guard cells and neighbouring cells at a magnification of $12.5 \times 10$. According to (Mulyani, 2006) explains that in stomata, two special cells limit the stomata, called guard cells, and some 
stomata in plants have two or more neighbouring cells that surround guard cells.

b. Catharanthus roseus, Adenium obesum, and Plumeria rubra have an Anomocytic/Ranunculaceous stomata type. Anomocytic/Ranunculaceous type stomata are stomata with their cover cells surrounded by specific cells that are no different from another epidermis (Traiperm et al., 2017). This is in line with (Resmi, 2019) in a journal entitled Stomatal Types In Monocot And Dicot Plants Within Flora of Nirmala College Campus explained that research on 40 plants collected, 16 plants showed anomocytic stoma, one of which was from the Apocynaceae family, Tabernaemontana sp. and Catharanthus roseus has Ranunculaceous type stomata, the covering cells surrounded by certain cells which are the same as another epidermis. This type of stomata is also known as anomocytic. The same thing is also explained by (Sharma, Dimple, Daulat Singh, Santosh K.Sharma, Seema Sharma \& Sharma, 2012) that Catharanthus roseus has Ranunculaceous stomata. Epidermal cells directly fuse with stomata and cover cells are surrounded by certain cells that are not different from the epidermis. Anomocytic type stomata are found in the paradermal cross-section of the leaf surface of Catharanthus roseus, Adenium obesum, and Plumeria rubra. Figure $4 \mathrm{a}$ shows the clustered stomata of Catharanthus roseus seen at a magnication of $4 \times 10$, Figure $4 \mathrm{~b}$ shows the presence of stomata on Adenium obesum with a magnication of $4 \times 10$, and Figure $4 \mathrm{c}$ shows many stomata on Plumeria rubra with a magnication of $4 \times 10$. In research (El-Taher et al., 2020). That the type of stomata in Adenium obesum varies in each species, namely tricytic, anisocytic, and tetracytic. Other researchers explained Bashir et al. (2020) that Catharanthus roseus has anisocytic and anomocytic stomata types. Other researchers explained Sarjani et al. (2017) that the type of stomata Piper ningrum in the Piperaceae family is anomocytic. This is in line with research Firdaus and Maasawet (2015) that Plumeria has an anomocytic stomatal type.

The distribution of stomata numbers is generally more on the lower surface than the upper surface of the leaves. This is a form of adaptation mechanism to the terrestrial environment (Tambaru, Elis, 2014). The Apocynaceae family groups that have the closest phenetic relationship in terms of their stomata type are Catharanthus roseus, Adenium obesum, and Plumeria rubra with Anomocytic or Ranunculaceous stomata types. Meanwhile, the Alamanda cathartica species have far-reaching phenetic relationships with the three species of the Apocynaceae family.

\section{Conclusion}

The relationship between the species in the Apocynaceae family is seen from the morphological and anatomical characteristics of the species, where the morphology observed is in the form of leaves, stems, roots and flowers with their characteristics. Based on the phenetic relationship between Plumeria rubra and Adenium obesum, they have a closer kinship than Catharanthus roseus. Meanwhile, Allamanda Cathartica formed an outgroup where the kinship was far from the three species. The anatomical character observed was in the form of stomata type, in which the stomata type in Allamanda cathartica was paracytic/rubiacous type, this type of stomata was surrounded by two other cells, namely, guard cells and parallel neighbouring cells. While Adenium obesum, Chatatrus roseus, and Plumeria rubra have anomocytic/ranunculaceous stomata type, this type of stomata is stomata with its cover cells surrounded by certain cells that are no different from another epidermis.

\section{Declaration statement}

No potential conflict of interest was reported by the authors.

\section{References}

Bashir, K., Sohail, A., Ali, U., Ullah, A., Ul Haq, Z., Gul, B., Ullah, I., Sunera, \& Asghar, M. (2020). Foliar micromorphology and its role in identification of the Apocynaceae taxa. Microscopy Research and Technique, 83(7), 755-766. https://doi.org/10.1002/jemt.23466

Campbell, A. dkk. (2012). Biologi Jilid 2 Edisi 8. Erlangga.

El-Taher, A. M., Gendy, A. E. N. G. E., Alkahtani, J., Elshamy, A. I., \& Abd-ElGawad, A. M. (2020). Taxonomic implication of integrated chemical, morphological, and anatomical attributes of leaves of eight apocynaceae taxa. Diversity, 12(9), 1-17. https://doi.org/10.3390/D12090334

El Gazzar, A., El-Ghamery, A., El-Saied, A., El-Kady, A., \& Khattab, A. (2018). Numerical re-assessment of the phenetic relationship between Apocynaceae and Asclepiadaceae. Taeckholmia, 38(1), 84-106. https://doi.org/10.21608/taec.2018.11941

Firdaus, M., \& Maasawet, E. T. (2015). Perbedaan Ukuran Dan Bentuk Stomata Tumbuhan Air Dan Tumbuhan Darat. Seminar Nasional I Biologi, Sains, Lingkungan, Dan Pembelajaran Pendidikan Biologi FKIP Universitas Mulawarman, 81-92.

H, George. F. George J, H. (2006). Biologi. Erlangga.

Haryanti, S. (2010). Jumlah dan distribusi stomata pada daun beberapa spesies tanaman dikotil dan monokotil. Buletin Anatomi Dan Fisiologi, XVIII(2), 21-28.

Mulyani, S. (2006). Anatomi Tumbuhan. Kanisius.

Noor, J. (2014). Metodelogi Penelitian. Kencana. 
Ping-Tao. (1995). Apocynaceae Flora of China. 16, 143-188.

Rahayu, S. E. H. (2008). Keanekaragaman Morfologi dan Anatomi Pandanus(Pandanaceae) di Jawa Barat. Vis Vitalis, 1(2), 29-44.

Rahmawati, Hasanuddin, \& Nurmaliah, C. (2016). Hubungan Kekerabatan Fenetik Tujuh Anggota Familia Apocynaceae. Jurnal Ilmiah Mahasiswa Pendidikan Biologi, 1(1), 1-9.

Resmi, P. R. A. T. (2019). Stomatal Types in Monocot and Dicot Plants within Flora of Nirmala College Campus , Coimbatore ,. International Journal for Research in Applied Science \& Engineering Technology, 7(III), 19801988.

Sarjani, T. M., Pandia, E. S., \& Wulandari, D. (2017). Famili Piperaceae di Kota Langsa. IPA Dan Pembelajaran IPA, 1(2), 182-191.

Sennblad, B., \& Bremer, B. (1996). The familial and subfamilial relationships of Apocynaceae and Asclepiadaceae evaluated with rbcL data. Plant Systematics and Evolution, 202(3-4), 153-175. https://doi.org/10.1007/BF00983380

Sharma, Dimple, Daulat Singh, Santosh K.Sharma, Seema Sharma, P. C. \& R., \& Sharma. (2012). Epidermal Studies of Some Plants of Family Apocynaceae. Asian Journal of Biochemical and Pharmaceutical Research, 2(1), 231236.

Steenis, V. (2008). Flora Cetakan ke-12. PT. Pradya Paramita.

Tambaru, Elis, A. I. L. dan S. S. (2014). Identifikasi Struktur Anatomi Stomata Penampang Membujur Daun Pada Beberapa Jenis Pohon Hutan Kota Unhas Makassar. Jurnal Alam Dan Lingkungan, 5(8), 5-10.

Traiperm, P., Chow, J., Nopun, P., Staples, G., \& Swangpol, S. C. (2017). Identification among morphologically similar Argyreia ( Convolvulaceae ) based on leaf anatomy and phenetic analyses. Botanical Studies, 58(25), 1-14. https://doi.org/10.1186/s40529-017-0178-6

Wahyu, D. (2016). Toga Indonesia. Airlangga University Press. 